\title{
IIUSIC $\odot_{\mathrm{L}} \odot_{\mathrm{GIST}}$
}

International Joumal of Music Studies

Trabzon University State Conservatory @ 2017-2020

Volume 4 Issue 1 June 2020

Research Article

Musicologist 2020. 4 (1): 78-100

DOI: $10.33906 /$ musicologist.734789

\section{DİLEK CANTEKİN ELYAĞUTU}

Sakarya University, Turkey

dcantekin@sakarya.edu.tr

orcid.org/0000-0002-0357-9148

\section{Records of Turkish Folk Dances from the Hungarian Academy of Sciences, Research Center for Humanities, Institute for Musicology}

\begin{abstract}
This study includes the first part of the results of the research titled "Examination of Literature on Turkish Folk Dances and Creating a Movement Notation Archive with Analysis Outputs" conducted within the scope of TUBITAK 2219 Post-Doctoral Research Fellowship Program. The research is designed to comprise three parts. The first part involves reviewing the archives of the Hungarian Academy of Sciences1, Research Center for Humanities, Institute for Musicology and existing literature regarding the subject, the second part involves notating the Turkish Folk Dances with Labanotation/Kinetography Laban, and the third part involves comparative analysis and interpretation of such dances notated in terms of Turkish-Hungarian Dance Folklore.

This article includes the findings and determinations related to the research on Turkish Folk Dances in the film collections found in the archives of the Institute for Musicology, Research Center for Humanities.

A Descriptive Survey Model has been used to obtain data. The information tags of the records found in the video archives have been examined, deciphered and corrected.
\end{abstract}

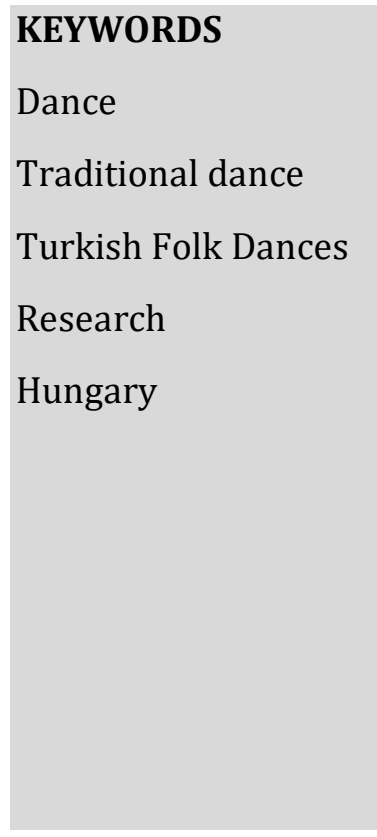

1 Institute for Musicology, Research Center for Humanities has not belonged to the Hungarian Academy of Sciences since last September. For this reason, it was expressed in as Institute for Musicology, Research Center for Humanities later in the article. 


\section{Introduction}

The first and earliest scientific studies in Turkey on Turkish Folk Dances started in the early 1900s. In the last period of the Ottoman Empire, there were two important figures that studied Turkish Folk Dances. These are Rıza Tevfik Bölükbaşı and Selim Sırrı Tarcan. “The article 'Dance and its Various Styles' published by Rıza Tevfik in 1909 in Memalik-i Osmaniye is one of the first written studies on Turkish Folk Dances. The first institutionalized study was a large field study organized by Darülelhan in 1926, which also involved folk dances" (Öztürkmen, 2014: 216). "A group of researchers including Yusuf Ziya Demircioğlu, Mahmut Ragıp Gazimihal, Ferruh Arsunar, and Abdülkadir İnan filmed many dances in Rize, Trabzon, Erzincan, and Erzurum, while also compiling many folk songs" (Öztürkmen, 2014: 216). In Turkey, studies were conducted with a focus on compiling Turkish Folk Dances, particularly in the 1940s, and compilation activities were organized in a number of cities. The dances compiled were filmed and, in the following years, taught to students in cities like Istanbul, Ankara, and Izmir, by association. This way, only the dances that were appreciated during shows attracted attention and became popular, whereas many other traditional dances were excluded from the repertoire and forgotten. Unfortunately, a large part of these original compilation records that were filmed could not be preserved and did not survive until today.

Looking at the literature on the subject, Ahmet Feyzi's (2015) article called "Erzurum Folk Songs in the Anatolian Folk Songs Book of Darü'l Elhan" incorporates details on Darü'l Elhan compilations, which is considered to be the first of the institutionalized compilation studies in Turkey. The study contributes to the project in the way that Turkish spiritual cultural productions were compiled in 16 works by Hungarian studies. Similar musicological studies were conducted by researchers such as Ribakof (1879), Pantosof (1890), Çlingaryan (n.d), Leysek (1890), Pahtikos (1905), and P. Komitas Vardapet (1905) in the same period in the regions populated by Turkish people. They identified the musical works of such regions and published their research in the format journal format in cities like St. Petersburg, Tashkent, and Budapest. These pieces of information serve as a basis for the research we will conduct in Hungary, increasing the probability of accessing the expected data.

During the early years of the Republic, 
"In early 1920s, the Ministry of National Education founded a cultural department for the purpose of collecting folklore products and included the folklore studies in the publications of the ministry during the first ten years of the Republic. Foreign experts and scientists were invited to Turkey for purposes such as preparing reports, improving the folklore studies, organizing folklore compilation trips and establishing a public museum. Following the recommendations and suggestions of Béla Bartók, Istanbul Conservatory compiled 2000 folk songs and published most of them during the years 1925-35" (Başgöz, 2011: 1540).

During such compilation studies, Hungarian Turkologist Ignácz Kunos participated in the studies alongside musicologists like Béla Bartók and Zoltán Kodály. The compilation works conducted by Hungarian musicologist Béla Bartók in Turkey were later published as 'Béla Bartók's Folk Music Research in Turkey by Ahmet Adnan Saygun'2 (Vikár, 1976) and Turkish Folk Music from Asia Minor (Bartók, 2017).

"It can be said that the systematic compilation of folk dances for teaching and staging purposes began in the 1940s and 1950s with the exception of Selim Sirrı Tarcan and Darülelhan examples" (Öztürkmen, 2014: 232). Conducted under the roof of community centers at first, compilation studies were also later supported throuth contests held by organizations such as the Association for Promoting and Sustaining Turkish Folk Dances, and the National Students' Federation of Turkey. Hundreds of traditional dances were performed at national holidays, celebrations and festivals, and spread and kept alive. Such compilation studies started only in more recent times and covered only the Anatolian geography. However, the cultural elements of the Turkish people who lived on the Ottoman territories that stretched from Eastern Europe to the Indian Ocean were excluded from such compilations. From the perspective of the history of Turkish Folk Dances, the information on the timeframe during the Ottoman Period is not comprehensive enough to determine the styles and characters of dances. Relevant findings reported by the dance scholar Öztürkmen as a result of her research are important in terms of the history of dance. "Although Ottoman Miniatures related to fields of performance such as dance, acrobatics and parade were addressed by art historians, there was relatively little interest in the analysis of movements in miniatures

2 This book that we took from Hungarian Academy of Sciences, Musicology Institute's Bartók Archive includes the compilation notes and musical notes handwritten by Bartók himself. The study also has a music archive consisting of two CDs. 
(Öztürkmen, 2016: 59)”. This leads to the inability to determine the geographies, from which the characteristics of the dances performed during the Ottoman period came.

While determining the laws and rules related to the formation, change, and spread of folklore events and products, folklorist Nail Tan argued, that "all changes and spreads in folk culture will occur through contact" (Tan, 2000: 16). We have chosen Hungary as our field site, as we thought cultural contact would be highest there. The similarities between Hungarian People and Turkish People, particularly regarding music cultures, are reflected in their dance cultures. For this reason, the research started in the region, the origins of which date back to Arpad, and which was, for many years, governed under the auspices of the Ottoman Empire.

The literature review on the subject of the research has shown that there are important relations and ties especially between Turkish and Hungarian cultures and histories. All the sources obtained touch upon the common grounds of the communities of the two countries and examine their relations in terms of historical, linguistic and musicological aspects. In particular, the sources that frequently talk about cultural similarity give clues that Turks and Hungarians come from the same lineage and such similarity may be reflected in all cultural productions today. Similarly, today's studies support this idea as well. Young Hungarian historian and dance researcher Erika Barabásı-Mocsárı builds her academic career on Turkish Folk Dances today. "The dance treasure of Hungarians and its place and role in the European dance tradition are now a subject that has been already studied and told. However, our job now and in the future is to look into the similarities to our folk dances in the East and the Eastern influences. Folk music studies are far ahead on this subject. This is because this subject was first researched by Béla Bartók in 1930s and János Sipos has been researching it, in his footsteps, since 1990s" (Barabási Mocsári, 2018:162). Although previous studies did not address the association of the traditional dance cultures of the two countries, today's researchers do not ignore the fact that the similarities found in their music and languages exist also in their dance cultures.

"Hungarians, with whom the Ottoman Empire had frequent contacts since the first years of its development, and struggled for more than 300 years, remained under Turkish rule for over 150 years since 1541" (Çolak, 2010: 373). It is a fact that Turkish identity, which 
existed as a demographic element for a long time in Hungary, continues to live in this region and/or has cultural effects that still persist. As a matter of fact, Hungarian scientists that look for the traces of their culture in the Turkish culture, have been highly curious about, and researched the elements of the Turkish Folk Culture. Such research is still ongoing, and Hungarian Musicologists and Ethnocoreologists trace their roots in the East in Turkey.

Some of these recent studies include "Karaçay-Malkar Folk Songs, a Trip to the Caucasus on the Track of Hungarian Folk Music" prepared by Sipos and Tavkul (2018) and Sipos (2009), In the Footsteps of Bartók in Anatolia, and Török Nepzéne II (Sipos, 1995).

Upon reviewing the literature on the subject, we can see that studies are not limited to the musical culture, and there are mutually important studies in the field of linguistics, too.

In Turkey, the Chair of Hungarology was founded as an equivalent of the Library of Oriental Languages in Hungary. Çoban (2016) talks about this philology chair and its functions, which was founded under the name of Hungarology in line with the special desire and directives of Atatürk when the Faculty of Languages, History, and Geography (DTCF), which would be the core of Ankara University, was being founded in 1935. Hungarogy, the primary purpose of which was to reveal, process, and analyze everything related to the historical past of this nation, as well as its present or past culture, was founded from the Turks' desire to explore the link between the Turkish and Hungarian roots.

Çalik (2015) mentions that it is a turning point in the Turkish-Hungarian cultural relations that Hungarian scientists are closely interested in the Turkish history, which they associate with their past, and accept Turkology as a "national science". It is indicated that the fact that the science of Turkology was born on Hungarian lands has been a driving force that has improved and continued Turkish-Hungarian relations. Additionally, he also talks about certain figures and studies that have strengthened Turkish-Hungarian relations. One of the figures who has contributed in this field is undoubtedly famous Hungarian Turkologist György Hazai. In 1965, exhibitions dedicated to "Turkish-Hungarian Relations in History" were organized in Istanbul, 
Ankara, and Tekirdağ, thanks to his initiatives. The cultural relations between the two countries were addressed in many ways in the exhibitions.

Bayram (2011) gives important information about why Turkish culture has been investigated by Western states. He states that a lot of research has been done especially in the field of language and history in order to build on a solid ground the relations between the Turkish-Hungarian communities, which are believed to be related within the framework of the Ural-Altaic theory. This study, which we have added to our literature, shows that Turkish Culture and Hungarian Culture should be explored not only based on language and history, but also based on dance, music, and other traditional arts.

Csáki, Kamalı and Yıldırım's (2016) work called About the Hungarian Folk Dances includes significant information about Hungarian Folk dance compilations and traditional folk dances, serving as a basis for the research to be conducted. The work talks about the Dance House movement's process of becoming a place where many cultural elements, such as folk music, handicrafts, and especially Hungarian traditional folk dances, are compiled and exhibited.

The Táncház (Dance House) movement was stared in the 1970s in Budapest. The collection of original traditional music that is played in dance houses today was started by composers and musicologists Béla Bartók and Zoltán Kodály; the tunes originate from Hungary and Transylvanian regions, which incorporate Hungarians living in Romania. A leading personality of the dance house movement, choreographer Sándor Timár, contributed to the dance material applied in dance houses, but the greatest contribution to establishing the large film collection on Hungarian traditional dances is the work of György Martin, one of the greatest personalities of Euopean folk dance research. He and his colleagues collected about 400,000 meters of film, mainly during the second part of the 20th century, not only on dances that existed within the present borders of Hungary, but also in the entire Carpathian Basin. They established the Folk Dance Archive, housed by the Institute for Musicology, which includes films, photos, manuscripts of interviews, and also a large collection of dance notation and motifs with 
the system called Kinetography Laban.3 They recorded not only the dances that existed within their borders, but also the dances in the entire Carpathian Basin, and created a collection of Hungarian traditional dances. The compilations made by ethnochoreologist, who worked at the Institute for many years, are published on the Internet Knowledge Base of Traditional Dances (Fügedi 2016b), Another example of a published collection of dances in notated form, is the representative book of Old Hungarian Dance Style (Ugros) (Fügedi and Vavrinecz, 2013). The Hungarians were able to create a map of the Hungarian Traditional Folk Dances by comparing their own dance culture to the dance cultures of all the neighbors, with whom they had been in contact, thanks to the method they used.

When we look at the traditional dance repertoires in Turkey, we see that compilations have been limited to only the political borders of the country and the dances have not been examined from an etymological point of view. Compilations made based on such an understanding have caused discussions and criticism in recent years. Furthermore, since the compilation works were not written in notation, popular and acclaimed dances have survived until today, whereas many of our traditional dances have been forgotten. Although the folklorists at the National Folklore Research Office (MIFAD) tried to notate Turkish Folk Dances and archive them for a period, these efforts were not continued.

Therefore, the traditional dance archives found in the Institute for Musicology, Research Center for Humanities have been examined first as part of the research. The information and findings discovered there have been recorded to be compared with the information and findings in the archives of our art and science departments. Thus, we have attempted to determine whether Turkish Folk Dances were compiled in the same quality and quantity as Turkish Folk Music by Hungarian scholars. (Béla Bartók, Zoltán Kodály, György Martin). In light of such determinations, the process of creating an updated archive regarding the literary history of Turkish Folk Dances will begin.

This study has been designed to initiate a literary research and study process that will contribute to the Turkish Folklore and Turkish Folk Dance Departments. This is

3 Labanotation, a.k.a. Kinetography Laban, is a tool that allows coding the movements through symbols, making it possible to record all the movements the human body is capable of. The writing of the movement is its alphabet. For more detailed information, please see: (Hutchinson Guest, 1998; 2005; Fügedi, 2016a). 
necessary, in order to notate and analyze dance archives from past to present, and to contribute to the creation of a literary archive.

Analysis is necessary to investigate the History of Turkish Folk Dances on European lands and to reveal the Turkish traces in the traditional dance culture in Europe. In addition, it is necessary to determine whether Hungarian musicologists compiled samples from Turkish Folk Dances during the Turkish Folk Music compilation studies they did in Anatolia.

Another reason that has made this research necessary is that the Turkish Folk Dance compilations have not been notated like music compilations, and they have disappeared over time. Whereas the Turkish Folk Music Compilations made during the same period by folklorists and musicologists, such as Mahmut Ragıp Gazimihal, Muzaffer Sarısözen, and Béla Bartók, are still kept in our archives, the Turkish Folk Dances compiled during the same period were not notated and preserved. There was an attempt to archive notations after the 1990s, but such efforts were not fruitful. Creating a written archive for not only ethnochoreology, but also in anthropology, dance anthropology, and dance history departments, is an important element in terms of the development of scholarship on dance. Scholarship requires first creating a common writing language and terminology. For such reasons, it will be possible for the art of dance to serve the field as a field of scholarship, if it can establish its own terminology through a writing system, and if it can be archived and analyzed. Many ethnochoreologists around the world approach areas of study with such awareness and care about the structural content, as well as the functional content of dance. The objective of this article, which is the first stage of the research, is only to transfer the findings. In the following studies, we is aim to determine the similarities between the Turkish and Hungarian Dance Cultures through a comparative analysis. Thus, while the history of Turkish Folk Dances will be defined with accurate and analytical values, a written archive, based on notation will also be obtained.

\section{Findings}

As a result of an approximately nine-month study, it has been determined that there are 12 films about Turkish Folk Dances at the Institute for Musicology Institute, Research Centre for the Humanities. A total of 28 Turkish Folk Dance shows from 14 different 
cities have been found. These regions are Bitlis, Elazığ, Artvin, Gaziantep, Trabzon, Adıyaman, Edirne, Diyarbakır, Bingöl, Silifke, Erzurum, Ankara, Kars, and Mut. If we classify these regions based on their styles, we can see halay, horon, hora, bar, zeybek, kaşılk, and karşılama from each style of 7 regions. Of these dances, the dances belonging to Bitlis, Diyarbakır, Ankara, the Black Sea, and Edirne regions have been selected and notated with Labanotation. Dances were filmed at different times during different organizations and by different ethnochoreologists. Each film reel in the Institute's archive has an information tag. These information tags provide as many details as possible, as recorded by the researchers, such as the date of the film recording, name of the organization, venue, researcher, the countries to which the filmed dances belong, the styles and names of the dances. Since information tags were handwritten by the researchers, there have been some problems with deciphering them at times, and because of this, some information is missing. The findings have been provided with the information tags and the archive numbers in the film archives of the Institute for Musicology, Research Centre for the Humanities. The decipherable information on the logbooks has been written below the logbook. 


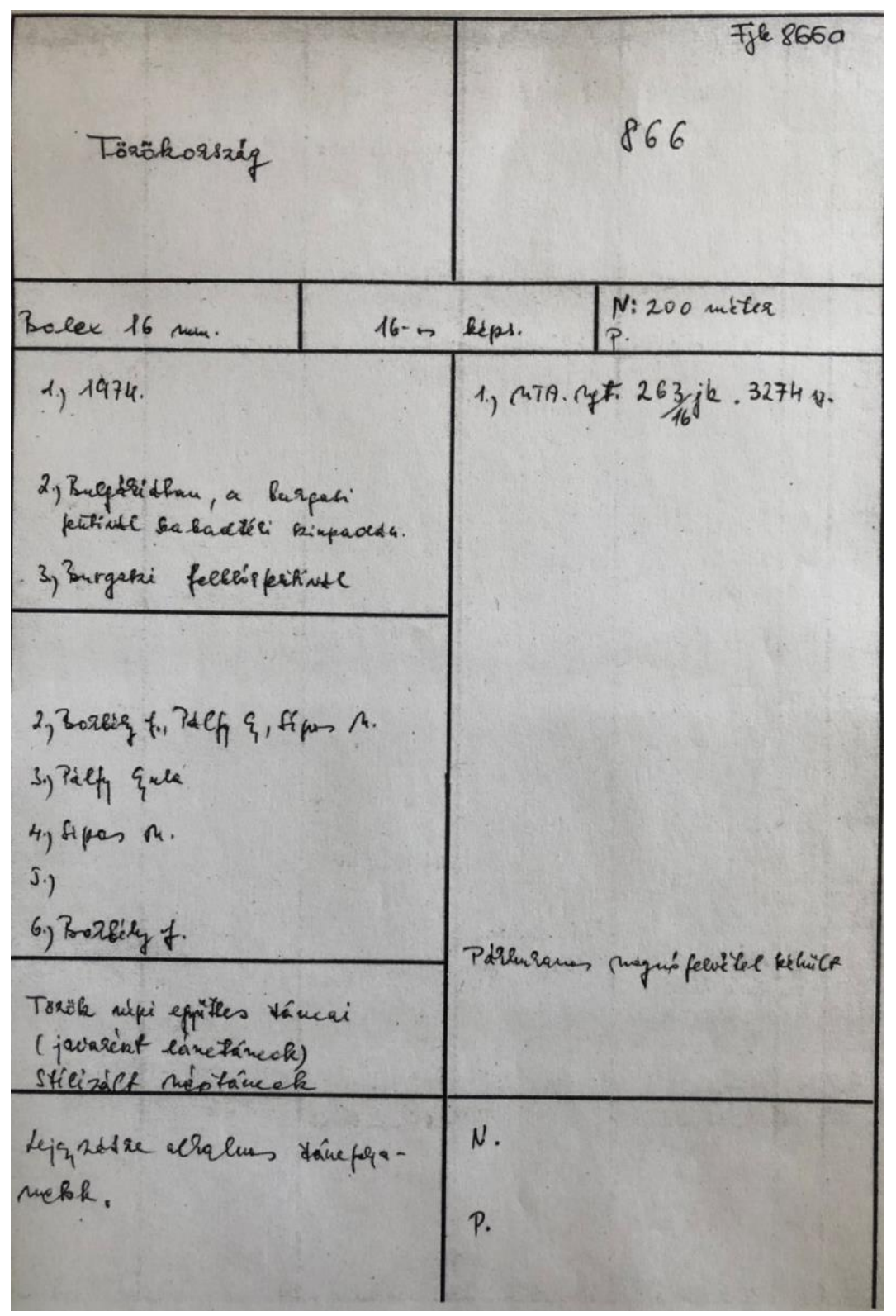

Figure 1. Logbook of Ft.866a.

Year: 1974

Place: Zakopane

Organization/Event: International Festival of Highland Folklore in Zakopane

Researcher: Palfy Gyula

Region: South East Anatolia

Type: Halay, Bar

Location: Bitlis

4 Ft. identifies the Film Collection of the Traditional Dance Archive in the Institute for Musicology, Research Centre for the Humanities. 
Dances: Ağır Govent, Meyroke, Değirmenci, Sepe (Sippi), Ağır Govent, Meyroke, Papuri, Harkuşta, Sepe (Sippi), Papuri, Harkuşta.

Performance: We determined that the dances were performed in their traditional forms (line, half circle, circle). The dances in the film roller number 688 belong to Bitlis Center Dances. The first dance, the Ağır Govent, is always mixed with dance Bitlis'de Beş Minare. The difference between the two dances is their direction: Bitlis'te Beş Minare is performed by going to the left and right, while the Ağır Govent is performed by going forward and backward (Mehmet Savaş, personal communication, September, 15 2018).

Gender: In the film, only male dances were performed. There were 8 male dancers.

Costumes: The costumes were traditional Bitlis costumes, which are mentioned in the Turkish Folk Dance literature.

Accompanying instruments: Davul, Zurna

Region: East Anatolia

Type: Halay

Location: Elazı̆̆

Dances: Delilo, Çayda Çıra, Fatmalı (Nure), Çayda Çıra:

Performance: It was determined that the dances were performed in their traditional forms (line, half circle, circle).

Gender: Male and female dancers were performed together by 5 male and 5 female dancers

Costumes: The men's costumes were traditional Elazığ costumes, which are mentioned in the Turkish Folk Dance literature.

Accompanying instruments: The film numbered 866 is a silent recording, there was no any other evidence of dance-accompanying instruments.

\section{Data of Ft. 970}

Year: 1977

Place: Zakopane

Organization/Event: International Festival of Highland Folklore in Zakopane

Researcher: György Martin

$970 / 8$

Region: Black Sea

Type: Bar, Horon, Halay

Location: Artvin

Dances: Hemşin Horonu, Coşkun Çoruh, Daldalan 
Performance: It was determined that the dances were performed in their traditional forms (line, half circle, circle).

Gender: Both male and female dances were performed by 8 male and 8 female dancers, performing together.

Costumes: The costumes seen in the film were compiled from different local clothes.

$970 / 17$

Region: South East Anatolia

Type: Halay

Location: Gaziantep

Dances: Mani, Çepikli (Havarişko)

Performance: It was determined that the dances were performed in their traditional forms (line, half circle, circle).

Gender: Male and female dances were performed by 13 male and 13 female dancers performing together.

Costumes: The costumes seen in the film were compiled from different local clothes. Trabzon, Gaziantep, and Caucasian Costumes were worned.

\section{Data of Ft. 994}

Year: 1978

Place: Istanbul Açıkhava Tiyatrosu

Organization/Event: Festival

Researcher: György Martin

$994 / 1$

Region: Black Sea

Type: Horon

Location: Trabzon

Dances: Sallama, Siksara, Sallama.

Performance: It was determined that the dances were performed in their traditional form (line). Akçaabat Horon consists of three parts. The first part is 'düz horon' section, second is 'yenlik' section and the third one is 'sert sallama' section. In this film, it was seen that the dance started from the third part of the dance.

Gender: 7 male dancers performed.

Costumes: The costumes were traditional Black Sea- Akçaabat costumes, which are mentioned in the Turkish Folk Dance literature.

Accompanying instruments: As seen in the film, kemençe player plays on the stage, in front of the dancers and accompanying them. 
$994 / 2$

Region: South East Anatolia

Type: Halay

Location: Adıyaman

Dances: Simsim (Simsimi), Çep, Halay, Trrge (Tirge).

Performance: The dances in the film were staged in a choreographic manner.

Gender: 10 male and 10 female dancers performed together

Costumes: The costumes were traditional Adiyaman costumes, which are mentioned in the Turkish Folk Dance literature.

Accompanying instruments: Only Davul was seen in the film.

$994 / 3$

Region: Marmara

Type: Karşılama, Kasap, Hora

Location: Edirne

Dances: Ahmet Bey, Kabadayı, Ahmet Bey, Zigoș, Zigoş Karşılama, Takuş, Eski Kasap.

994/4

Region: South East Anatolia

Type: Halay

Location: Diyarbakır

Dances: Gelin Halayı, Delilo, Kadın Halayı, Diyarbakır Halay, Diyarbakır Halay, Çaçan, Çepik.

Performance: It was determined that the dances were performed in their traditional form (line).

Gender: 5 male and 5 female dancers performed together.

Costumes: The costumes were traditional Diyarbakır costumes, which are mentioned in the Turkish Folk Dance literature.

Accompanying instruments: As seen in the film, Davul and Zurna were played on the stage.

$994 / 5$

Region: South East Anatolia

Type: Halay

Location: Gaziantep

Dances: Kırıkhan, Dokuzlu, Bağlantı-Çepikli, Dokuzlu. 
Performance: The dances in the film were staged in a choreographic manner.

Gender: 10 male and 10 female dancers performed together

Costumes: The costumes were traditional Gaziantep costumes, which are mentioned in the Turkish Folk Dance literature.

994/6

Region: Black Sea

Type: Horon

Location: Trabzon

Dances: Horon Kurma, Sallama.

$994 / 7$

Region: East Anatolia

Type: Halay

Location: Bingöl

Dances: Esmer (Harani), Meyremo.

Performance: The dances in the film were staged in a choreographic manner.

Gender: Only male dances were performed.

Costumes: The costumes were traditional Bingöl costumes, which are mentioned in the Turkish Folk Dance literature.

994/8

Region: Mediterranean

Type: Kaşık

Location: Silifke

Dances: Yayla Yolları, Silifke'nin Yoğurdu, Keklik.

Performance: The dances in the film were staged in a choreographic manner. In the town Anamur, Mut and Silifke, there was no tradition of men and women dancing together. According to the Sünni tradition, it was a shame of women to dance in the community. For this reason, women had danced amoung themselves and men had danced amoung themselves. Also in the period of Ottoman, before going to the plateau, there were entertaintment in the city, and Greek women were brought to dance to Anamur (Ahmet Doğan, personal communication, January, 30 2019). But nowadays this tradition is not valid.

Gender: 8 male 8 female dancers performed together.

Costumes: The costumes were traditional Silifke costumes, which are mentioned in the Turkish Folk Dance literature. 
$994 / 9$

Region: Black Sea

Type: Horon, Bar

Location: Artvin

Dances: Şeyha (Şahlan), Sarı çiçek.

Performance: The dances in the film were staged in a choreographic manner.

Gender: 10 male 10 female dancers performed together.

Costumes: The costumes were seen to be traditional Artvin costumes, which are mentioned in the Turkish Folk Dance literature.

\section{Data of Ft.996}

Year: 1978

Place: Pest

Organization/Event: 6. Dunamenti Festival

Researcher: Pálfy Gyula, Görgy Martin, János Szabo...

$996 / 1$

Region: East Anatolia

Type: Halay

Location: Adıyaman

Dances: Simsim (Simsimi), Çep, Goftan, Düz (Hellocan), Fadile, Galuç.

Performance: The dances in the film were staged in a choreographic manner.

Gender: 10 male and 10 female dancers performed together.

Costumes: The costumes were traditional Adiyaman costumes, which are mentioned in the Turkish Folk Dance literature.

Accompanying instruments: As seen in the film, Davul and Zurna were played on the stage.

$996 / 2$

Region: East Anatolia

Type: Halay

Location: Elazığ

Dances: Bıçak (Elazığ Zeybeği), Delilo, Halay.

Performance: The dance which involved knives, is a choreographic choice. The other dances were all performanced in their traditional forms.

Gender: 8 male and 8 female dancers performed together. 
Costumes: The costumes were traditional Elazığ costumes, which are mentioned in the Turkish Folk Dance literature.

\section{Data of Ft.1037}

Year: 1979

Place:

Organization/Event: Festival

Researcher: Laszlo Felföldi, Gyula Palfy.

\section{$1037 /$}

Region: East Anatolia, South East Anatolia, Black Sea.

Type: Bar, Halay, Horon.

Location: Erzurum, Gaziantep, Bingöl, Bitlis, Akçaabat

Dances: Başbar.

Performance: The Başbar dance of Erzurum is traditionally performed in four sections. Firs section is moving forward, second is progressing in a circle form, third one is bouncing and the fourth one is kneeling and final.

Gender: Only male dances were performend

Number of dancers: 4 men dancers

Costumes: The costumes worn in the record are the traditional Adiyaman and Trabzon costumes.

\section{Data of Ft.1066}

Year: 1980

Place: Fransa / Confolens

Organization/Event: Festival De Confolens Dance Et Musiques De Monde / Ataköy Folklor Kulübü

Researcher: Zoltán Varga, Jakab Jozsef

\section{6}

Region: South East Anatolia, East Anatolia, Black Sea

Type: Halay, Horon.

Location: Gaziantep, Diyarbakır, Trabzon

Dances: Oğuzlu (Gaziantep), Çaçan, (Diyarbakır), Çepikli (Havarişko), (Diyarbakır), Siksara + Sallama (Trabzon), Horon Kurma (Trabzon). 


\section{Data of Ft.1099}

Year: 1981

Place: Bursa

Organization/Event:

Researcher: Laszlo Felföldi

Region: Black Sea

Type: Horon

Location: Trabzon

Dances: Horon Kurma, Sallama, Sıksara, Horon Kurma, Sallama, Sallama, Sıksara, Sallama, Kozan Gel, Kozan Gel Sallaması, Yandan Alma (Tonya), Parmak Ucu (Tonya), Sallama, Bıçak.

Performance: It was determined that the dances were performed in their traditional forms (line).

Gender: Male dances were performed by 6 male dancers

Costumes: The costumes were traditional Black Sea- Akçaabat costumes, which are mentioned in the Turkish Folk Dance literature.

Accompanying instruments: As seen in the film, kemençe player plays on the stage, in front of the dancers and accompanying them.

\section{Data of Ft.1101}

Year: 1981

Place: Pest

Organization/Event: 7. Duna Folkor Festivali

Researcher: Csapó Karoly, Pálfy Gyula, Nemeth I., Pesovar Ernö, Fesovar Ferench, Lanyi A.

$1101 / 1$

Region: South East Anatolia

Type: Halay

Location: Diyarbakır

Dances: Delilo, Çaçan.

Performance: It was determined that the dances were performed in their traditional form (line).

Gender: 6 male and 6 female dancers performed together.

Costumes: The costumes were traditional Diyarbakır costumes, which are mentioned in the Turkish Folk Dance literature. 
Accompanying instruments: As seen in the film, Davul and Zurna were played on the stage.

$1101 / 2$

Region: East Anatolia

Type: Halay

Location: Adlyaman

Dances: Simsim (Simsimi), Çep, Halay (Goftan), Galuç.

Gender: 6 male and 6 female dancers performed together.

Costumes: The costumes were traditional Adlyaman costumes, which are mentioned in the Turkish Folk Dance literature.

Accompanying instruments: As seen in the film, Davul and Zurna were played on the stage.

\section{Data of Ft.1171}

Year: 1984

Place: Budapest

Organization/Event: 8. Duna Folklor Festivali

Researcher: Csapó Karoly, Gyula Pálfy, Felföldi László

\section{4}

Region: Central Anatolia

Type: Seymen

Location: Ankara

Dances: Seymen Zeybeği, Hüdayda.

Performance: The dances in the film were staged in a choreographic manner. These performances in the film number 1171c were applied very close to the traditional form. The dances performed are well-staged example for the performance of traditional 'Seymen Dances Performance'.

Gender: Only male dances were performed.

Costumes: The costumes were traditional Ankara Seymen costumes, which are mentioned in the Turkish Folk Dance literature.

\section{Data of Ft.1180}

Year: 1984

Place: Samsun

Organization/Event: Festival 
Researcher: Zoltán Karácsony

Region: East Anatolia

Type: Bar, Halay, Yallı.

Location: Kars

Dances: Sarı Seyran, Dans: Pappuri (Papuri).

Performance: The image in the film does not give an idea about the quality of execution.

Gender: 6 male and 6 female dancers performed together.

\section{Data of Ft.1197}

Year: 1984

Place: Mersin

Organization/Event: Mersin Festivali

Researcher: Imre Fapp, Miklós Szalóczy, Anikós Péterbeneze

Region: Mediterranean

Type: Kaşık

Location: Mut

Dances: Karakuş Zeybeği, Tımbıllı, İrfani, Çay Zeybeği.

Performance: It was determined that the dances were performed in their traditional forms (line, circle, half circle).

Gender: 6 male dancers performed.

Costumes: The costumes were traditional Mut costumes, which are mentioned in the Turkish Folk Dance literature.

Accompanying instruments: As seen in the film, Klarnet and Koltuk Davulu were played on the stage.

\section{Data of Ft.1443}

Year: 1993

Place: İstanbul

Organization/Event: Festival

Researcher: János Fügedi, Gyula Pálfy, Zoltán Karácsony

Region: Black Sea

Type: Bar, Horon, Halay.

Location: Artvin

Dances: Düz Horon (Vazriya). 
The film record was not found of this information receipt.

\section{Conclusion}

The data obtained from this study shows us the interest of Hungarian Ethnochoreologists in Turkish Folk Dances. This can be interpreted as Hungarian ethnic researchers' interest in the traditional dance folklore of different cultures, or an attempt to find their links to the East.

Another notable aspect of the data is that the data contains important information about the period, to which it belongs. Although the available data is not a result of a Field Survey, it contains highly important information about Turkish Folk Dances, festivals, and dance organizations held in the 1970s and 1980s. Some of the recordings in the archive are silent films, and some are sound films. Films numbered 866,970, 994, 996b, 1037, 1066, 1099, 1180, 1197 are silent films. The dances in these films are identified based on the motif structures of the dances, the costumes that the dancers wear, and counting the rhythm patterns and frequencies of the motifs in the movements.

Since the films numbered 996a, 996c, 1101, 1171 are sound films, the melodies of the music of the dances and the musical instruments used in these recordings can be easily detected.

Among the dances in the films, the dances performed in the reels numbered 994, namely the dance peculiar to Diyarbakır, and the dances numbered 1037, 1066, 1099, 1171 were filmed in the open air, with no stage. It is established that the dances in film reels numbered 996a and 1101 are performed on a stage in the open air. It is seen that all other dances are performed on venue stages.

We established that the dances peculiar to Adıyaman, Bitlis, Diyarbakır, and Elazığ, the dances peculiar to Akçaabat in Eastern Black Sea Region, and the dances peculiar to Silifke and Mut in Mediterranean Region, are mainly preferred for Halay, Horon, and Kaşılk (folk dances) respectively to be represented in international folklore organizations in the 10 year period. The general characteristics of these dances are performed by dance ensembles. We can see that the dances peculiar to Edirne province in the Marmara region were also performed. As for the interior parts of Turkey, only the 
dances peculiar to the Ankara province were performed. As a result of the study, we can observe that the dances peculiar to the Aegean region were not chosen to be performed in international folklore organizations between 1974-1981. This data can be interpreted as the dance called Zeybek, which is performed commonly in the Aegean region, is generally a solo performance and that such dances did not attract much attention at that time.

When we check dates on the records in the archive, we can see that folklore festivals held in different cities were recorded every two years between 1974 and 1981, and especially Turkish dance ensembles were filmed in these performances. Some of the recordings were made on professional stages, whereas some others were filmed purposely in areas off-stage. This information can be interpreted as the Hungarian ethnochoreologists wanting to record Turkish dances purposely outside off-stage and archive better quality data. For the years between 1981 and 1993, there were no recordings of Turkish Folk Dances in the archive. The most recent recording is of 1993, and the film indicated in this record could not be found in the archive.

We can say that the costumes identified in the film are generally traditional costumes of the relevant region. In some dances, it seems that dance ensembles made their stage performances with costumes from different regions, and this was considered to be a situation that occurred at a later date, due to organizational conditions.

It is established that traditional forms of dances are mostly preserved, but there are choreographic additions in only a few performances. It is understood from the performances that folklore clubs, which represent Turkey in International folklore festivals achieved quite successful performances and had mastery of the local dances.

Based on the films in the archive of the Institute, the dances of Mut, Ankara, and Silifke regions have come to the present day almost unchanged, with the same style of performance. The performances of these dances are of rather high quality, and natural. However, the dances performed in Edirne were performed differently from their current performance. In today's dances of Edirne region, there is a section called Zigoş Karşılaması, also known as Drama Karşılaması after the Zigoş dance. As a result of the interview with the informant in the region, we found out that this section is performed only at local weddings, and not taught in any other institutions and places (Serdar Sayın, 
personal interview, February, 10 2018). Such details will be expressed more comprehensively in the publications to be made after this study.

\section{REFERENCES}

Bartók, Béla. (2017). Küçük Asya'dan Türk Halk Musıkisi [Turkish Folk Music from Asia Minor]. (Aksoy, Bülent. Çev.) İstanbul: Pan Yayıncılık.

Başgöz, İlhan. (2011). “Türkiye'de Folklor Çalışmaları ve Milliyetçilik” [Folklore Studies and Nationalism in Turkey], Turkish Studies - International Periodical for The Languages, Terature and History of Turkish or Turkic. 6(3): 1535-1547.

Bayram, Bülent. (2011). Macar Türkoloji Araştırmalarında Çuvaş Folklorü [Chuvash Folklore in Hungarian Turcology Studies], Türkbilig. 22(87): 87-120.

Barabási Mocsári, Erika. (2018). “Macaristan Halk Oyunlarının Araştırma Tarihi ve Yöntemleri" [Research History and Methods of Hungarian Folk Dances], IV. Uluslararası Müzik ve Dans Kongresi Proceeding Book. [IV. Uluslararası Müzik ve Dans Kongresi]. Gülbeyaz Kürşad; Yazıcı, Tarkan (Eds), (158-163). Marmaris: Müzik Eğitimi Yayınları.

Csáki, Èva; Kamalı, Hatice and Yıldırım, Rabia Sena. (2016). "Macar Halk Oyunlarına Dair" [About to the Hungarian Folk Dance], Motif Akademi Halkbilimi Dergisi. 9(17): 199204.

Çalik, Fatma. (2015). Soğuk Savaş Döneminde Türkiye-Macaristan İlişkileri [TurkeyHungary Relations During Cold War], Balkan Araştırma Enstitüsü Dergisi. 4(2): 33-60.

Çoban, Erdal. (2016). Türkiye'de Bir Macar Türkolog Tibor Halasıkun [A Hungarian Turcologist Tibor Halasık in Turkey], DTCF Dergisi. 56(2): 414-439.

Çolak, Melek. (2010). Atatürk-Macarlar ve Türk Tarih Tezi [Atatürk-Hungarians and Turkish History Thesis], Selçuk Üniversitesi Türkiyat Araştırmaları Dergisi. 27: 371-402.

Feyzi, Ahmet. (2015). Darü'l Elhan'a Ait Anadolu Halk Şarkıları Defterlerinde Erzurum Türküleri [Erzurum Folk Songs in the Anatolian Folk Songs Books of Darü'l Elhan], A. Ü. Türkiyat Araştırmaları Enstitüsü Dergisi [TAED]. 54: 829-856. 
Fügedi, János. (2016a). Basics of Laban Kinetography for Traditional Dancers. Budapest: Institute for Musicology, Research Centre for the Humanities.

Fügedi, János. (general editor). (2016b). "The Data of the Knowledge Base of Traditional

Dances." Version 1, dx.doi.org/10.23714/nzntk.ntt.publ.101777. Retrieved from http://db.zti.hu/neptanc_tudastar/pdf/biblio/101777.pdf

Fügedi, János; Vavrinecz, András. (2013). Old Hungarian Dances Styles, The Ugros, Anthology. Budapest, Hungary: L’Harmattan - MTA Zenetudományi Intézet.

Guest, Ann Hutchinson. (1998). Choreo-Graphics, A Comparison of Dance Notation Systems From the Fifteenth Century to the Present. New York: Routledge.

Guest, Ann Hutchinson. (2005). Labanotation, A System of Analyzing and Recording Movement Fourth Edition. New York: Routledge.

Öztürkmen, Arzu. (2014). Türkiye'de Folklor ve Milliyetçilik [Folklore and Nationalism in Turkey], (4 ed). İstanbul. İletişim Yayınları.

Öztürkmen, Arzu. (2016). Rakstan Oyuna: Türkiye'de Dansın Modern Halleri [From Raks to Game: Forms of Modern Dance in Turkey]. İstanbul: Boğaziçi Üniversitesi Yayınevi.

Tan, Nail. (2000). Folklor (Halkbilimi)[Folklore], Genel bilgiler. İstanbul: Artmedia.

Sipos, János. (1995). Török Nepzéne [Turkish Folk Music]. II. Budapest: MTA Zenetudományi Intézet,

Sipos, János. (2009). Anadolu'da Bartók'un İzinde. İstanbul: Pan Yayıncıllk.

Sipos, János; Tavkul, Ufuk. (2018). Karaçay-Malkar Halk Şarkıları - Halk Müziğinin İzinde Kafkasya'ya Bir Seyahat [Karachay-Malkar Folk Songs - A Trip to the Caucasus in the Footsteps of Folk Music]. Ankara: Bengü Yayıncılık

Vikár, László. (1976). Béla Bartók's Folk Music Research in Turkey. (Byron, Samira B. Trans.). A. Budapest: Akadémiai Kiadó. 